\title{
Motor vehicle lease agreement with fiduciary warranty
}

\author{
Agustining* and Ningrum Natasya Sirait \\ Doctoral Program in Law, Graduate School, Universitas Sumatera Utara, Medan, Indonesia
}

\begin{abstract}
Purchasing motor vehicles with instalment (credit) is currently becoming favourite choice by many people including people who live in plantation and agriculture area. There are several reasons, such as easy prerequirements, low down payment and saving time. The financing institutions that generally deal with motor vehicle credit are financing companies and banks. Although, they are different in their operational legal basis, in practice, financing company and bank fall under the category of fiduciary warranty agreements. This study focus on the potential fraud on law in financing of capital goods. This study used the normative and empirical legal research methods. In the end of the study, it found that it used loan financing with fiduciary guarantee not a lease agreement. As a consequence, the use of fiduciary warranty by financing company in a lease does not accord with the law and considered to be illegal. Last but not least the study found that Ministry of Finance and the Financial Services Authority (Otoritas Jasa Keuangan/OJK) as supervisory agencies financing business must to ensure law enforcement, certainty and effective oversight. OJK should provides sanctions for financing companies which do not comply in accordance with the legal provisions.
\end{abstract}

\section{Introduction}

The increasing public need for motor vehicles either as a private transportation or as a main vehicle for working has driven a high public interest to own a motor vehicle. It appears in all areas in Indonesia including plantation and agriculture areas. Owning a motor vehicle has become a primary need for most people. There are some reasons why nowadys, owning motor vehicle became a primary need. First, using motor vehicle both 2 wheels or 4 wheels are more practicee rather than using rental vehicle for example for a farmer, he/she can bring directly the harvest back to her/his home. Secondly the public transport conditions are neither sufficient nor comfortable due to its condition and the expensive price. As an impact, it encourages people to have their own vehicle. ${ }^{[1]}$

Vehicles are motors driven by a technical equipment to move and mostly used for land transportation. ${ }^{[2]}$ This study specifically discussed motor vehicle which use 4-wheels and 2wheels motor vehicles for individuals as good renter. To be able to own a motor vehicle, people are provided with many ways on payment options. If they do not have cash to buy,

*Corresponding author: ning_mkn@yahoo.com 
purchasing on credit becomes the most preferred choice.

The option of purchasing on credit can be realized with the financing help of banks or leasing companies. Both banks and leasing companies play the same role in helping people to own a motor vehicle through monthly instalment. However, they differ in the legal operation. Bank is a business entity that collects funds from the community in the form of savings and distributes them in order to improve the standard of living of many people. Commercial bank can provide services in the payment transactions. ${ }^{[3]}$ On the other hand, leasing is a financing activity in the form of capital goods provision either under an optional lease (finance lease) or a non-optional lease (operating lease) to be used by the Lessee for a specified period of time on a periodical basis. ${ }^{[4]}$

Although they both have similar role, they differ in their legal basis in terms of regulation and procedures for vehicle acquisition. In banking practices, the bank's function is to provide bailout funds in cash. The bank as the creditor and the customer as the debtor are bound by a principal agreement in the form of a credit agreement. It is then followed by an additional agreement (accesoir) in the form of a fiduciary warranty. This situation is potential to make fraof of law happened.

Fiduciary is only an additional agreement (accesoir) which serves as a tool for the bank to execute if the debtor violates the agreed credit agreement. The bank does not hold the guaranteed goods physically. However, it is protected by the law under the fiduciary warranty registered with the Ministry of Justice and Human Rights of the Republic of Indonesia, in the form of a fiduciary warranty certificate. ${ }^{[5]}$ The holders of fiduciary warranty are protected because the certificate has a written phrase "For the sake of justice under the Almighty God" that has similar executorial power as the decision of a court which bears legal force. If the debtor breaches the agreement, the fiduciary holder shall have the right to sell the object of fiduciary warranty on his/her own power. ${ }^{[6]}$

The concept of fiduciary warranty is the transfer of ownership on the basis of trust of the material right. ${ }^{[7]}$ Material right here means the right to an object (a motor vehicle) which can be owned and transferred. (Insert references in endnote). The characteristic or nature of the transferable material right is absolute. It follows the object wherever and/or with whoever it's located. Furthermore, it has the preferential right. ${ }^{[8]}$

According to the prevailing regulations in Indonesia, the process or procedure of obtaining a motor vehicle through a leasing company involves 4 (four) parties namely the Lessor or leasing company, the Supplier or provider of goods, the Lessee and goods renter, and the insurance company. ${ }^{[9]}$

The leasing procedure can be described as follows: (1) the Lessee determines the required motor vehicle, then the Lesse selects and determines the Supplier. (2) the Lessee completes a leasing application and meets the requirements to be subsequently submitted to the Lessor. (3) The Lessor examines the financial condition and ability of the Lessee, if approved then the Lessor requires the Lessee to sign a leasing agreement and at the same time the Lessee will sign an insurance agreement with an insurance company designated by the Lessor for a good renter. (4) The contract and the goods renter purchasing payment shall be signed by the Lessor and Supplier. (5) The Supplier hands the goods renter over to the Lessee. (6) the Lessee pays the leasing fee periodically according to the agreed leasing agreement. ${ }^{[10]}$ The procedure can be drawn in Fig 1. 


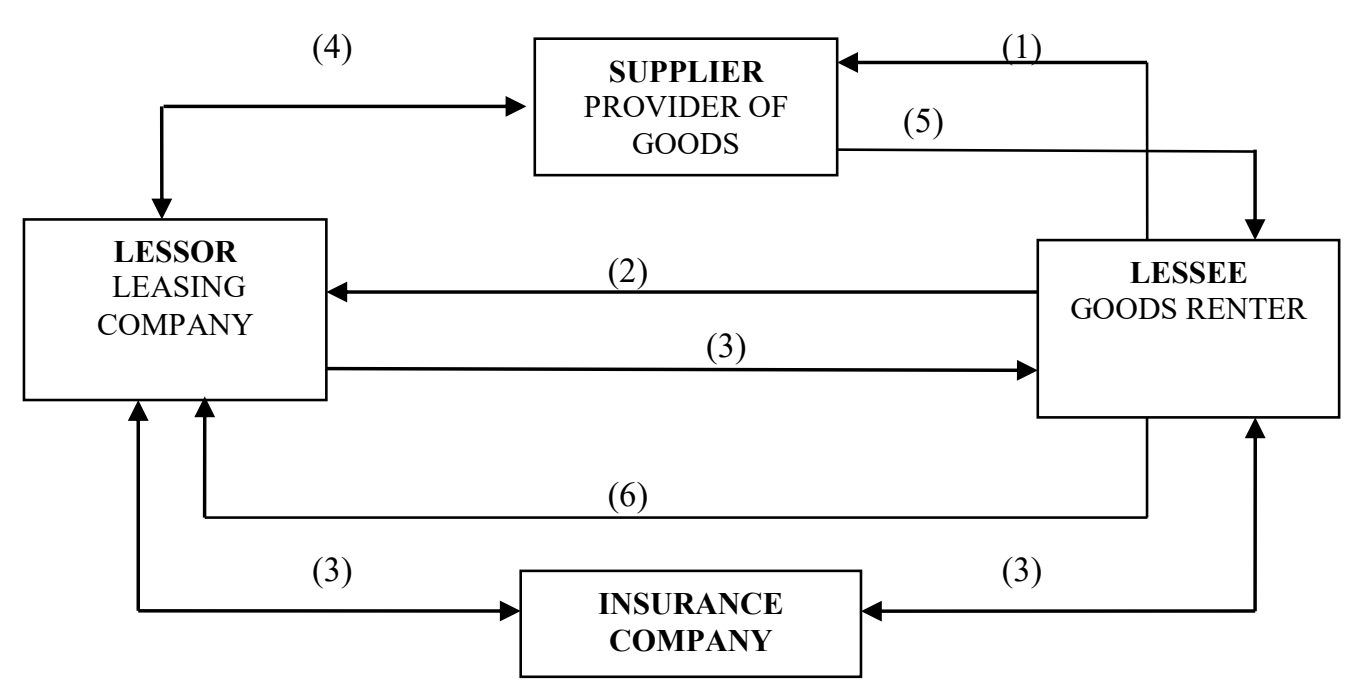

Fig. 1. Leasing Procedure

The nature of a Leasing contract is a rental activity. According to the procedure, it is clear that the buyer of good renter is the Lessor and during the course of the leasing agreement, the ownership of the vehicle goes to the Lessor.

At the signing of a leasing agreement, the Lessee as a motor vehicle renter may agree that he/she will purchase the leased motor vehicle at the end of the leasing term. As such, the last leasing payment is considered as a sale session between the Lessor and the Lessee. At that moment, a purchasing agreement between the Lessor and the Lessee should be proceed with the name transfer or registration of ownership right from the Lessor to the Lessee.

In fact, a mutual financing agreement or contract is made between the Lessor and the Lessee, with the Lessee's obligation to make the down payment plus the cost of vehicle taxes and other expenses which follows the same financing bank procedure as. The registration of the motor vehicle has already been made on behalf of the Lessee, with a mutual financing agreement or contract made and a notary-signed fiduciary warranty subsequently registered at the Ministry of Justice and Human Rights of the Republic of Indonesia. Therefore, if the Lessee including the goods renter suffers a financial blockage in the instalments (default), the Lessor directly confiscates the good renter based on the executorial power of the fiduciary certificate as commonly found in banking practices.

With respect to the credit purchasing system, the Government regulates uniform amount of down payment in the Procedure for Motor Vehicle Loan as stated in the External Circular Letter of the Bank of Indonesia Number 14/10/DPNP dated 15 March 2012 on the Implementation of Risk Management in Bank Providing House Ownership Loan and Motor Vehicle Loan. The down payment, here in after referred to as Down payment (DP), is a prepayment or advance cash to buy a motor vehicle on credit. This fund originates from the debtor (self-financing) and is set at least $25 \%$ (twenty five percent) for the purchasing of two-wheel vehicle and 30\% (thirty percent) for the purchasing of four-wheel vehicle for non-productive purposes. ${ }^{[11]}$ This rule applies equally to both leasing companies and banks.

Based on the facts above, this research conducted to respond to the following questions: a) Why leasing companies are able to use fiduciary warranty for motor vehicle in their leasing practice? b) What is the legal consequence of the fiduciary warranty agreement made by the motor vehicle leasing companies? 


\section{Research method}

The study conducted based on an empirical legal approach. The empirical legal approach is the science of law which perceives law as a fact which can be construed or observed and is value-free. ${ }^{[12]}$ The definition of value-free here is that the study of law should not be dependent or influenced by the researcher's personal assessment. ${ }^{[13]}$ The empirical legal research aims at measuring how a law works in asociety. ${ }^{[14]}$ Bahder Johan Nasution's in his book Metode Penelitian Ilmu Hukum (Research Methods in Law), the main character or feature of empirical legal research ${ }^{[15]}$ is its emphasis on observation. This relates to the objective and empirical nature of the science itself. It is to include knowledge of empirical law which seeks to observe the prevailing legal facts in the society, in which it requires knowledge to be observed and openly demonstrated. The starting point of the observation lies in the facts or social facts that exist and live in the society as the living culture of the people. ${ }^{[16]}$

In addition to empirical study, this study also used a normative legal study, that is research on legal principles, legal sources, and scientific and theoretical laws and regulations that can analyze and discussed the issue. ${ }^{[17]}$ The strength of the normative legal study lies in the sequential steps which are easily explored by other legal scientists. ${ }^{[18]}$

With the empirical and normative research methods, the extent to which a law works in the society can be studied. This study revealed or dealt with the fact that is can be observed with the rationale. The concepts or research terms must be firmly applied to the world of research. As such, it is expected to provide an answer to the fill in the gap that occurs amidst the existing regulations.

\section{Discussion}

\subsection{The use of fiduciary warranty agreements on leased motor vehicles.}

Fiduciary is the ownership transfer of an object on the basis of trust in a condition of the goods renter, whose ownership right is transferred, remains in the possession of the object owner. ${ }^{[19]}$ It is clear that fiduciary (Fidusia Eigendom Over dracht) is a transfer of ownership based on trust. ${ }^{[20]}$ The party gives full confidence to the other party to transfer their ownership right where the objects are considered as collateral.

Another definition of fiduciary (Fiduciaire Eigendoms Overdracht/FEO) is the transfer of ownership right on the basis of confidence in the debtor's goods used as a collateral to the creditor whereas the physical goods still remain in the control of the debtor. ${ }^{[21}$ From the definition, fiduciary can be distinguished from fiduciary warranty. Fiduciary is a process of transferring ownership rights and fiduciary warranty is a collateral given in the form of a fiduciary. A fiduciary warranty is accessoir (additional to) the principal agreement, that is a financing or credit agreement. ${ }^{[22]}$

The government ${ }^{[23]}$ regulated that the nature of material right as a fiduciary object is absolute. The material right has a defendable possession against anyone; the material right follows the object (droit de suite) no matter who possess the good; the material right has droit de preference, the holder of the material security is entitled to repayment earlier than other creditors. In practice, purchasing a motor vehicle can be done in two ways:

\section{a. Under bank's financing scheme}

The debtor submits a request for funding to a particular bank. After being evaluated and meeting the requirements, the bank together with the debtor purchases the motor vehicle in 
cash (funded by the bank) at the dealer. At that time, the registration of vehicle is made on behalf of the debtor. Because the finance is supported by the bank, the debtor and the bank have signed a principal agreement that is a debt agreement or credit agreement. Further to guarantee the payment of debt in an orderly manner, the bank also makes an additional agreement in the form of a fiduciary agreement. Furthermore, the vehicle remains controlled by the debtor, while the bank as the creditor only keeps the credit agreement, fiduciary warranty agreement, Book of Motor Vehicle Owner (BPKB) and Certificate of Fiduciary Warranty.

In order to ensure the legal certainty in this fiduciary warranty, the law applies the principle of fiduciary warranty registration. Registering fiduciary warranty legally protects the interests of the guarantor, the recipient and the third party. The grant of material right to the creditor as a fiduciary recipient means the grant of a fiduciary guarantee certificate. The grant of parate execution right and separatist creditor status indicates the intent of the legislator to grant a strong position to the creditor. ${ }^{[24]}$ If the debtor defaults (wanprestatie), the bank can confiscate the collateral for execution because the bank has the executorial power based on the fiduciary warranty certificate.

The creditor's authority to confiscate the collateral from the debtor in default cases cannot be done by force. For the safe, orderly, smooth and accountable execution of fiduciary warranty and for the safety and security of the fiduciary recipient, fiduciary guarantor, and/or the public from acts which may cause loss of property and/or personal safety, the creditor may submit an application for the execution safeguard in writing by the fiduciary guarantor or his/her lawyer to the Regional Police Head or District Police Head at the place of execution. ${ }^{[25]}$

\section{b. Under a leasing company financing scheme}

However, the scheme is different if a good renter obtained from a financing company. The Lessor as the owner of the goods rents the equipment for a certain period of time. So, it requires a leasing agreement. The Lessee is required to pay a rent periodically for a certain period of time. While the leasing company, as the owner of the goods, has the option to submit (sell) or buy the leased goods at the end of the leasing term.

Leasing is a financing activity in the form of capital goods provision through either an optional lease (Finance Lease) or a non-optional lease (Operating Lease) to be used by the Lessee for a specified period of time based on instalments. ${ }^{[26]}$ Whereas rent-to-buy (hire purchase) is an act of buying and selling goods in which the seller sell goods by taking into account any payments made by the buyer through repayment of the goods price which has been mutually agreed upon and which is bound in an agreement. The ownership of the goods can only be transferred from the seller to the buyer after the price is paid in full. ${ }^{[27]}$ Throughout the hire purchase period, the ownership right of the goods has not being transfer or still in the possession of the seller. Once the object is paid off, its registration is transferred to the buyer's name.

Fiduciary warranty in a lease is not necessary. In a lease, the creditor has full rights because the goods are formally owned by the Lessor although they are materially controlled and used by the Lessee. If fiduciary warranty is used, the leased goods must be registered on behalf of the renter so that the ownership of the goods can be guaranteed by fiduciary. However, as stated aboved that fiduciary warranty as the additional agreement in a leasing contract is not regulated by the Indonesian law which adheres to the civil law system. If there is an uncertain sale of goods, the right of ownership will not be granted until the goods comply with the contract. ${ }^{[28]}$

Hire purchase is an agreement not specifically regulated in the Civil Code. However, since Book III of the Civil Code embraces an open system, any parties may enter into 
agreements which are not specifically regulated in the Civil Code. ${ }^{[29]}$ Hire purchase is a mixed agreement in which the terms of purchase and leasing agreement apply. The legal consequences of the two agreements are totally different. In a purchase agreement, the ownership of goods are immediately transferred upon the payment, while in a leasing agreement, there is no transfer of ownership.

\subsection{The legal consequences of fiduciary agreements made by motor vehicle leasing companies.}

The financing agreement is fall under an unnamed agreement. This means that all agreements made by the parties in accordance with the principle of freedom of contract, which has not been regulated under the Civil Code, are deemed valid as long as they are not contrary to the law, public order and morality. ${ }^{[30]}$ Article 1319 of the Civil Code states, every nominat or innominat agreement is subject to the general provisions of the agreement law. The hire-purchase agreement as an innominat agreement is also subject to general terms of an agreement such as the requirements for a valid agreement and default cases.

According to Article 1 paragraph 5 of Presidential Regulation of Indonesia No. 9 of 2009, Leasing is a financing activity in the form of providing goods either by leasing with option rights (Finance Lease) or leasing without option rights (Operating Lease), to be used by the Lessee for a specified period of time based on instalment payments. Based on voluntary payments which accompanied by the right to choose for the company, either to purchase the capital goods concerned or to extend the leasing term based on the agreed remaining value. ${ }^{[31]}$

Hire purchase is an act of buying and selling goods in which the seller performs the sale of goods by taking into account any payments made by the buyer through repayment of the goods price which has been mutually agreed upon and which is bound in an agreement, and the ownership of the goods can only be transferred from the seller to the buyer after the total price is paid in full. ${ }^{[32]}$

Financing in the form of capital goods should be made lease agreement but in fact used loan financing with fiduciary guarantee Thus, if a fiduciary agreement is applied to a leasing guarantee, it will be determine as illegal. It is illegal since in a lease the ownership right has not been transferred from the seller to the buyer before the price is paid in full by the buyer. While the fiduciary warranty is used to guarantee the ownership right of goods in which the goods remain controlled by the owner. Because of its legal defects, fiduciary warranty in a lease should have no legal effect. If the Lessee defaults, the Lessor cannot execute on the basis of a fiduciary warranty certificate.

As a result of the leasing fiduciary, many people are disadvantaged by the debt collector who has unilaterally confiscated a motor vehicle from a defaulted debtor. The action is without taking into account the debtor's right to the payments previously made. The government seems to know nothing about the arbitrary practice of this lease and not yet respond to growing concern over this practice. In addition, the Financial Services Authority (OJK) as the supervisory agency in businesses, in this case supervision of banking services, must intervene..

\section{Conclusion}

\subsection{Summary}

Fiduciary warranty in a Lease is not necessary because in a leasing finance the creditor still has full rights. The goods formally belong to the company although they are materially 
controlled and used by the renter. If fiduciary warranty is used, the leased goods must be registered on behalf of the lessee so that the ownership of the goods may be guaranteed by a fiduciary.

Under the Indonesian law which adheres to the civil law system, fiduciary warranty in a lease is not regulated. In practice, if a lease of a motor vehicle uses a fiduciary warranty, the agreement will be deemed unlawful, because in a leasing agreement, the ownership right has not been transferred from the seller to the buyer unless the price is paid in full by the buyer.

\subsection{Recommendation}

The Indonesian Financial Services Authority (OJK) as the supervisory agency in businesses, in this case supervision of banking services, must intervene or against leasing practices that are not comply with. It is expected that OJK would provide sanctions on the violations. It is expected that the agency can provide legal certainty for the consumer as the lessee and the balance of rights between the vehicle renter (lessee) and the leasing company as the owner of the vehicle. Therefore there will be no arbitrary practice of leasing in handling a case of defaulted lessee.

\section{References}

1. I.W. Putra, Minat masyarakat Indonesia akan transportasi umum, web.unair.ac.id/.../f_71227_Minat_Masyarakat_Indonesia_Akan_Transportasi_Umu... retrieved on 30 April 2018.

2. https://id.wikipedia.org/wiki/Kendaraan_bermotor, retrieved on13 March 2018.

3. The Decree of the Minister of Finance of the Republic of IndonesiaNumber 1169/Kmk.01/1991 dated on 27 November 1991 on Leasing Activities Article 1 (a).

4. Law Number 7 of 1992on Banking Business Article1 (1) and (2) and President of the Republic of Indonesia Regulation Number 9 of 2009 on Financing Institution Article $1(5)$.

5. Law Number 42 of 1999 on Fiduciary Warranty, Article 14.

6. Law Number 42 of 1999 on Fiduciary Warranty, Article 15.

7. I.D. Purnamasari, Kiat-kiat cerdas, mudah dan bijak memahami masalah hukum jaminan perbankan, p. 83, (Kaifa, Bandung, 2014).

8. The Letter of the Ministry of Law and Human Rights of the Republic of Indonesia Number: C.HT-1.10-74 dated on 27 September 2006 on Guidelines for Fiduciary Registration.

9. Z. Asyhadie, Hukum bisnis, prinsip dan pelaksanaannya di Indonesia, p. 107, (Rajawali Pers, Jakarta, 2017).

10. Z. Asyhadie, Hukum bisnis, prinsip dan pelaksanaannya di Indonesia, p. 108, (Rajawali Pers, Jakarta, 2017).

11. Circular Letter of the Bank of Indonesia Number 14/10/DPNP dated 15 March 2012, on Implementation of Risk Management in Bank Providing House Ownership Loan and Motor Vehicle Loan, point IV on Down Payment of Motor Vehicle Credit System.

12. B.J. Nasution, Metode penelitian ilmu hukum, p.81, (Mandar Maju, Bandung, 2008). 
13. B.J. Nasution, Metode penelitian ilmu hukum, pp.81-82, (Mandar Maju, Bandung, 2008).

14. B.J. Nasution, Metode penelitian ilmu hukum, p. 123, (Mandar Maju, Bandung, 2008).

15. B.J. Nasution, Metode penelitian ilmu hukum, pp. 124-125, (Mandar Maju, Bandung, 2008).

16. B.J. Nasution, Metode penelitian ilmu hukum, p.124, (Mandar Maju, Bandung, 2008).

17. S. Soekanto and S. Mamudji, Penelitian hukum normatif suatu tinjauan singkat, p. 13, (Raja Grafindo Persada, Jakarta, 1995).

18. J. Ibrahim, Teori \& metodologi penelitian hukum normatif, p. 278, $3^{\text {rd }}$ Edition, (Bayumedia Publishing, Malang, 2007) (cited from P.M. Hajon).

19. Law Number 42 of 1999 on Fiduciary Warranty, Article 1.

20. Law Number 42 of 1999 on Fiduciary Warranty, Article 1.

21. H. Hadisaputro, Pokok-pokok hukum perikatan dan hukum jaminan, p.50, (Liberti, Jogjakarta, 1984).

22. I.D. Purnamasari, Kiat-kiat cerdas, mudah dan bijak memahami masalah hukum jaminan perbankan, p.88 (Kaifa, Bandung, 2014).

23. Ministry of Law and Human Rights of the Republic of Indonesia, The letter Number C.HT.-1.10-24 dated on 27 September 2006, in I.D. Purnamasari, Hukum jaminan perbankan, pp.83-84, (PTMirzan Pustaka, Bandung, 2014).

24. J. Satrio, Hukum jaminan, hak jaminan kebendaan, p. 180, (Citra Aditya Bakti, Bandung, 2007).

25. Regulation of the Police Department of the Republic of Indonesia Number 8 of 2011 on Fiduciary Warranty Execution Safeguarding, Article 2 jo Article 7 (a).

26. President Regulation Number 9 of 2009 on Leasing Companies ("Perpres 9/2009"), Article 1 (5).

27. http://www.hukumonline.com/klinik/detail/cl5033/perbedaan-leasing-dan-sewa-beli, retrieved on 14 March 2018.

28. P. de Cruz, Perbandingan sistem hukum, common law, civil law and socialist law,p. 553, (Nusa Media, Bandung, 2016).

29. Suharnoko, Hukum perjanjian: Teori dan analisa kasus, pp.64-64, (Kencana, Jakarta, 2004)

30. T. Kamelo, Filosofi dan aspek hukum fidusia dan pembiayaan (Masalah hukum, perjanjian, wanprestasi dan eksekusi), in a Law Seminar of PT Mandiri Utama Finance, Jogjakarta, 25 January 2018.

31. M. Djumhana, Hukum perbankan di Indonesia, p. 214, (PT Citra Aditya Bakti, Bandung, 1996).

32. Article 1 Letter a Ministry Decree 34/1980. 